Climate risk perceptions and adaptation decision-making at pÿNordic farm scale a typology of risk responses

Käyhkö, Janina

2019-11-02

Käyhkö , J 2019 , ' Climate risk perceptions and adaptation decision-making at Nordic farm pÿscale a typology of risk responses ', International Journal of Agricultural Sustainability , vol. 17 , no. 6 , pp. 431-444 . https://doi.org/10.1080/14735903.2019.1689062

http://hdl.handle.net/10138/321998

https://doi.org/10.1080/14735903.2019.1689062

acceptedVersion

Downloaded from Helda, University of Helsinki institutional repository.

This is an electronic reprint of the original article.

This reprint may differ from the original in pagination and typographic detail.

Please cite the original version. 
Climate Risk Perceptions and Adaptation Decision-Making at Nordic Farm-Scale - a Typology of Risk Responses

Janina Käyhkö

Ecosystems and Environment Research Programme, University of Helsinki, Helsinki, Finland

Helsinki Institute of Sustainability Science (HELSUS), University of Helsinki, Helsinki, Finland

P.O. Box 65 (Viikinkaari 1, 4403), 00014 University of Helsinki, Finland

janina.kayhko@helsinki.fi 


\title{
Climate Risk Perceptions and Adaptation Decision-Making at Nordic Farm-Scale - a Typology of Risk Responses
}

\author{
Agriculture in the Nordic countries is a sector, where farmers are facing climatic \\ challenges first-hand with little policy guidance on climate change adaptation or \\ climate risk management. Adaptation practices emerging at the farm scale have \\ potentially harmful outcomes that can erode the agricultural sustainability. So far, \\ farm-scale decision-making on adaptation measures is scarcely studied, and a \\ thorough assessment of risk perceptions underlying adaptation decision-making \\ is required in the Nordic context to inform adaptation policy planning. In this \\ qualitative case study, the climate risk perceptions of Nordic farmers and \\ agricultural extension officers are examined. As a result, a typology of risk \\ responses is presented, showing three dominant patterns within highly dynamic \\ and contextual adaptation processes at farm scale: risk aversive, opportunity \\ seeking and experimental. The typology represents the variation within \\ adaptation processes that further stress the need for participatory adaptation \\ policy development in agriculture.
}

Keywords: climate change risk; adaptation; risk management; Nordic agriculture; farmer

\section{Introduction}

Climate change adaptation is an adjustment process to climate change and its effects on human systems, which are realized as adaptation measures, in other words, responses to climate risks and vulnerabilities, as well as to seizing the related opportunities (Noble et al., 2014). In this widely used definition climate risk constitutes of three accountable elements: climatic hazard, exposure, and vulnerability to the risk (ibid.). In the case of agriculture, the hazard of increased weather extremes, for example, can develop into a climate risk when crop yields are exposed to rapid excess precipitation, the inflicted field is especially vulnerable to flooding and/or the crop is sensitive to downpours. More broadly, risk is argued to be a relative concept regarding the ambiguity and uncertainty related to the knowledge of the outcomes, and the likelihood of the hazard (Stirling, 2007) 
with respect to the values of the risk perceiver (Aven \& Renn, 2009). Moreover, Thomalla, Downing, Spanger-Siegfried, Han and Rockström (2006) claim that focus should be placed on the 'processes and dynamics of exposure and responses' to climate risks rather than to what actually is at risk.

The need to understand decision-making under climate-related risks in climate sensitive sectors is widely recognised (Keshavarz \& Karami, 2014; Treby, Clark \& Priest, 2006; Juhola et al., 2016b). As a response, studies on the relation between climate risk perceptions and decision-making in climate sensitive natural resource sectors, such as agriculture (Li, Juhász-Horváth, Harrison, Pintér \& Rounsevell, 2017), fish production (Lebel, Whangchai, Chitmanat, Promya \& Lebel, 2015), and forestry (Eriksson, 2014; Vulturius et al., 2018), have emerged. These studies broaden out the technical risk and vulnerability appraisal, commonly related to risk management approaches to adaptation (see e.g. Joes \& Preston, 2011), to encompass public experience and affective approach to risk and vulnerability (Slovic, 2000; Dessai et al., 2004; Gardezi \& Arbuckle Jr, 2017). This wider conceptualisation is discussed in terms of risk responses (see e.g. van der Linden, 2014) and protection motivation induced action (Norman, Boer \& Seydel, 2005; Grothmann \& Patt, 2005; Dang, Li, Nuberg \& Bruwer, 2014) when describing individual or private level of climate change adaptation.

The climate risk perceptions of Nordic farmers have been assessed as part of studies focusing on general climate change perceptions (Woods, Nielsen, Pedersen \& Kristofersson, 2017) and multi-sectoral climate risk management (Harjanne et al., 2016). Recent studies have shown that Nordic farmers perceive risks and opportunities from the upcoming and already observed climatic changes and they are responding with traditional and novel agricultural measures directed towards reducing risks or building adaptive capacity (Juhola et al., 2017; Peltonen-Sainio \& Jauhiainen, 2014; Jørgensen \& 
Termansen, 2016). These adaptation pursuits nevertheless hold potential for unintended harmful outcomes to the farmers themselves and to the sustainability of the agricultural systems (Neset, Wiréhn, Klein, Käyhkö \& Juhola, 2018). In the Nordic countries, agricultural adaptation is rather farm-based than policy driven (Wiréhn, 2018). Moreover, the development of Nordic adaptation policy has been lacking a stakeholder viewpoint (Klein \& Juhola, 2014), which is considered crucial in understanding the preconditions for change in behaviour at the practical level of adaptation.

This study consists of interviews with farmers and agricultural extension officers, who work with farmers and other agricultural actors to aid decision making at the farm scale. Both stakeholder groups are appreciated as holders of indispensable knowledge and insights relevant to this study (Welp, de la Vega-Leinert, Stoll-Kleemann \& Jaeger 2006). This qualitative single-case study examines the complex process of adaptation decisionmaking in the contemporary context where climate change adaptation, risk responses and agricultural production are not inevitably separable (Yin, 2014, p. 16). Adaptation is assessed as a process and intention rather than an outcome (sec. Rickards, Ison, Fünfgeld \& Wiseman, 2014). The study addresses the following research questions:

(1) How do farmers perceive climate risk in Nordic agriculture?

(2) How do these risk perceptions influence climate change adaptation at the farm level?

The study sets out to apply the protection motivation theory (PMT) framework (Norman et al., 2005; Grothmann \& Patt, 2005; Dang et al., 2014) to a case in Uusimaa region (Finland) and examines the climate risk perceptions, the adaptation assessment and the adaptation intentions of the agricultural stakeholders in the region. Three dominating patterns of risk responses that explain the risk perception driven adaptation are identified. 
These patterns imply that responses to climate risk and adaptation policy are likely to vary within agriculture. These findings further support the previous calls for participatory planning of agricultural adaptation policy which accounts for diverse risk perceptions.

\section{Theory and Methods}

Protection motivation theory $(\mathrm{PMT})^{1}$ (Norman et al., 2005) builds on an understanding that fear appealing communication (e.g. news on strong correlation between smoking and cancer) evokes either adaptive responses (e.g. decision to quit smoking) or non-adaptive responses (e.g. neglect the news and continue smoking). The adaptation decision-making process in the PMT framework composes of 1) risk perception which subsequently leads to 2) appraisal of the coping capability, leading potentially to 3) increased protection motivation and eventually to behavioural changes (Norman et al., 2005; Grothmann \& Patt, 2005). The PMT framework has previously been applied to the adaptation context in agriculture to broaden the scope of modelling individual adaptation intentions (Dang et al., $2014 \mathrm{a} ; \mathrm{b}$; c), as well as decision-making in adaptive capacity assessments (Grothmann \& Patt, 2005).

In this study, PMT is operationalised by focusing on the direct and indirect implications of climate risk, adaptation assessments and adaptation intentions, according to the risk perception driven adaptation decision-making model (Fig.1), where the crossing of a perceived risk threshold launches an adaptation decision-making process. In this model, climate risk perception consists of the individual reflections of

\footnotetext{
${ }^{1}$ Originally introduced by Rogers $(1975 ; 1983)$ as a psychological theory of fear-appeals effect
} on attitude changes and human behaviour, protection motivation theory (PMT) has been revised several times. A reconstructed version of PMT by Norman et al. (2005) is adapted and applied in this study. 
psychological and socio-cultural factors on the variables of climate risk: hazard, exposure and vulnerability (Noble et al., 2014; Oppenheimer et al., 2014, p. 1069). Individuals express these perceptions through experiences, expectations and interpretations related to climatic and non-climatic stressors, such as experiences of climate events and expectations of risk management, and through knowledge and awareness of climate change (Treby et al., 2006; Jørgensen \& Termansen, 2016). The risk perceptions indicate contextual attributes of risk, such as what is perceived to be under threat (Dang et al., 2014b) and when.

The adaptation assessment emerges from the risk perception and consists of the appraisal of adaptation effectiveness, costs and the individual capability to perform adaptation (Dang et al., 2014a). These perceptions of effectiveness, capability and costs are socio-cognitive indicators for the adaptation decision-making process (Grothmann $\&$ Patt, 2005). Both self-assessed high or low self-efficacy and the costs of a measure, if assessed as unbearable, have an effect on the direction of the decision-making process (Dang et al., 2014a). The assessment process is exposed to socio-economic factors, such as incentives and disincentives, and to psychological and socio-cultural factors, such as climate beliefs, habit and subjective norm (Dang et al., 2014a; c), as well as other nonclimatic stressors, such as institutional arrangements, social norms, economic conditions, and other cultural and political factors (Räsänen et al., 2016; Smit \& Skinner, 2002).

Adaptation intention is elicited as an outcome of the assessment indicating protective motivation and it can manifest as actual or planned adaptation measures or strategies (adaptation action) (Smit \& Skinner, 2002), including the potential for unintended negative outcomes of adaptation efforts i.e. maladaptation (Juhola, Glaas, Linnér \& Neset, 2016a; Noble et al., 2014). Disregarding adaptation by fatalism, wishful 
thinking or denial can result in lack of protection motivation and/or a non-actualised adaptation intention (no adaptation action) (Dang et al., 2014a; Grothmann \& Patt, 2005).

[Figure 1 near here]

\section{Study Site}

Adaptation is acknowledged in regional and sub-regional mitigation and adaptation strategies and sectoral guidelines in Uusimaa, Southern Finland (Keskitalo, 2010; ELY, 2012, Keski-Uudenmaan Ympäristökeskus, 2013; Peltonen-Sainio et al., 2017). The expected climatic changes and weather variability will bring about increased total precipitation, milder winters, more extreme weather events (such as hailstorms, spring droughts and downpours), longer growing season, northern expansion of suitable crop cultivation areas, and increased risk of pests, weeds and plant diseases that challenge and benefit agriculture (Peltonen-Sainio et al., 2017; Olesen \& Bindi, 2002; Maracchi, Sirotenko \& Bindi, 2005). So far, the identified opportunities include the introduction of new profitable cultivated plants and plant varieties, and higher productivity (ibid.).

Agriculture in the region is crop production oriented and the yields are directly more vulnerable to climate change than animal production (Peltonen-Sainio et al., 2017, p. 11), especially due to the erosion sensitive fields and soil type, and the long coast line (ELY 2012). Uusimaa region plays a significant role in the Finnish crop yield production and the climatic risks thus reach beyond the regional population and economy.

\section{Interviews}

Interviews were considered as a stakeholder dialogue (Welp et al., 2006) to elicit the novel topic of farm scale adaptation decision-making and agricultural adaptation. These interviews were semi-structured, allowing flexibility regarding the discussed topics and 
the depth of discussions (Hirsjärvi \& Hurme, 2008, pp. 34-38). Sampling criterion was limited to the dominant agricultural activity in the region. The participants were selected through snowball sampling, based on the recommendations from other agricultural actors in the region and the previous interviewees to find the 'hidden group' of knowledgeable stakeholders with experience on adaptation (Atkinson \& Flint, 2001). An introduction to the means and aims of the study was given when contacting the interviewees the first time as well as before starting the interviews. It was explained that the interviewees could withdraw their participation at any time and that their personal information is not included in any analysis or publication of the results. Location and time for the interviews was chosen based on participants' preference. The interviews started with questions on climate change related experiences and expectations, followed by questions on adaptation (assessment, intention, measures) and potential maladaptation, when necessary ${ }^{2}$. In general, the interview guide was freely followed to allow a naturally flowing discussion. The interviewer (author) kept track of the discussed topics with simple hand-written markings on a notebook and on a printed version of the interview guide which allowed directing the discussion back to unaddressed topics in a suitable moment. The sample's saturation point was reached when the interviews started repeating the same discussions (Hirsjärvi \& Hurme, 2008; Malterud, Siersma \& Guassora, 2016). The interviews were audio-recorded and transcribed in a convention typical for content analysis, describing talk, simple annotations of laughter and other expressions, pauses and emphasis (Hirsjärvi \& Hurme, 2008).

[Table 1 near here]

\footnotetext{
${ }^{2}$ See the supplemental online material for the operationalisation.
} 
The limitations of a small sample in-depth stakeholder interviews are related to the coverage of the sample and the interpretation of the discussions (Yin, 2014). Some interesting insights on the climate risk perceptions of the more than 2500 Uusimaa farmers have certainly been missed. However, the 'full spectrum of interests', as Welp et al. (2006) put it, is not aimed for in this study, but the focus is on the generally representative stakeholder perceptions.

\section{Analysis}

A general methodology of qualitative content analysis, commonly used for detecting individual perceptions from interviews, focusing on what the interviewees say was followed (Hirsjärvi \& Hurme, 2008). The methodological approach is adaptive: the research questions were iteratively revised during the data-collection and the analysis (Yin, 2014, p. 65). First, the data was reduced into a thematic map by coding the individual negotiations of risks and responses (following the PMT framework) and then organised into a logical model of adaptation processes (sec. Yin, 2014) that explained the relation between risk perceptions and adaptation decision-making (Yin, 2014, pp. 147150; Halperin \& Heath, 2012; Tuomi \& Sarajärvi, 2003), resulting in a typology of the risk responses ${ }^{3}$.

The quality of the data in a qualitative study depends on how successfully the research questions are operationalised in the interview guide and how much the interviewer effects the interviewee. Biases in the research process can arise during and after the interviews, and this was minimised with a clear and well-argued research plan

\footnotetext{
${ }^{3}$ See the supplemental online material for the thematic map.
} 
and an interview guide that drew on the literature on case-study methodology (Yin, 2014), stakeholder participation (Welp et al., 2006) and qualitative content analysis (Halperin \& Heath, 2012; Hirsjärvi \& Hurme, 2008; Tuomi \& Sarajärvi, 2003).

\section{Results}

\section{Perception of Climatic Stressors and Risks}

This section presents discussions of climatic challenges i.e. stressors reflecting perceptions of direct or indirect risks to farming and agricultural adaptation that constitute of the climate risk variables (hazard, exposure, vulnerability).

The climatic stressors that were raised during the interviews were in line with the current scientific understanding (e.g. Olesen \& Bindi, 2002; Juhola, Klein, Käyhkö \& Neset, 2017). Increased precipitation, droughts, temperature, weather variability and extreme weather events were acknowledged as up-coming and already experienced challenges. The discussed climate risks were based on knowledge from media, colleagues, and professional literature and internet sources; as well as on experienced extreme events. Climate change was generally regarded as a fact, but uncertainty regarding the outcomes and time-scales of climate change were raised and the causal links between certain weather variations and climate change were deliberated. Questioning the origins of the experienced variations is exemplified in an excerpt from a farmer: 'But this has nothing to do with climate change. It was just one of those odd summers and growing seasons.' (Farmer 3:10).

Based on experience, the variability and unpredictability of weather conditions were perceived to hinder the timely and reactive farm system management the most, especially along with growing farm sizes in the region. Perceptions of the most prominent hazards and the seriousness of the risks varied depending on the experienced extreme 
events and the temporal vicinity of the experiences. This manifests in a quote from a farmer discussing how they decided to implement buffer zones to the field sides by the flood sensitive river: 'It was then after the severe floods in summer 2004 when we did it.' (Farmer 6:5). Similarly, lately experienced harmful downpours and long periods of precipitation were highlighted in discussions, although droughts and increasing temperatures have been even more harmful for the farm revenues and will pose more severe threats in future. Furthermore, droughts seldom cause extra work, whereas risks related to increased precipitation are directly consequential to increased work-load on the field.

The indirect risks of adaptation measures were recognized and associated to climatic and non-climatic stressors, as well as to opportunities, such as those brought about by a longer growing season. While frequently discussed in a positive sense, longer growing season was also seen as negative, bringing increased pest, disease and fungi invasions that harm agriculture generally, and result in potential increased pesticide use that can causes risks to ecology and especially to organic farming. These types of negative outcomes of adaptation measures i.e. maladaptation had been encountered or were expected with measures on the field, with crop selection and with water protection. Generally, they concerned farm income, soil quality, labour intensity, pesticide usage and coping capacity ${ }^{4}$

The range of discussed risk allocation can be identified using two scales: systemic and temporal. The systemic range covers the agro-ecological components: crop yield, the field and the surrounding environment, as well as the production system parts, such as

\footnotetext{
${ }^{4}$ A full list of detected climatic challenges and the related perceived direct and indirect risks can be found from the supplemental online material.
} 
the farm economy, the local economy and food production. Crop yield and quality are affected by all climatic challenges, which in return affect the farm income seasonally. In terms of the temporal scale, farmers stated that they think in terms of the growing season, highlighting the seasonal nature of the activity. However, the discussed risks related to cultivation practices, environmental impacts, the sensitivity of agricultural productivity, soil quality, and local economic viability often relate to long term visions and scales beyond the farm level. An example of a broader scale effect to food security is presented by an advisor:

Regarding the [unexceptional] weather events --- is the seed-corn production secured? -- Are farms prepared for this type of bad years with a seed-corn reserve --- so that there would not be a regional or nationwide shortage of the most important crops and their seeds? It used to be typical that there were these reserves at farms. (Officer 3:8).

More importantly, the respondents emphasised that poor maintenance and unfavourable weather conditions can decrease soil quality and it can take even decades of careful maintenance to recover good quality. This is crucial as soil quality was assessed to be the limiting factor of the productivity in Uusimaa crop farming, meaning that even with all other factors, such as water, light and nutrition, available the productivity will not increase, if soil is packed or its permeability is poor or both.

\section{Adaptation Assessment and Perceived Role of Non-Climatic Stressors}

This section expands on the indicators of adaptation assessment (perceptions of adaptation effectiveness, adaptation costs and individual capability to perform adaptation) reflected in discussions of expectations and experiences related to adaptation actions. The described assessments evolve from the climate risk perceptions in the PMT framework, and particularly address the role of non-climatic stressors in the adaptation decision-making process. 
The perceived self-efficacy to perform adaptation varied from low to high, reflecting one's trust in own expertise, and on experiences, expectations and the proximity of perceived success or failure in adaptation. The role of communality, networks and family as resources were emphasised with regards to high or sufficient self-efficacy, whereas the lower self-efficacy perceptions related to discussions on the role of factors outside the farm, such as, markets and chance. Experience with adaptation measures was assessed as a highly relevant factor in defining self-efficacy and further the efficacy of the adaptation measures. In addition, experiences and observations from other practitioners and information from agricultural publications were used to assess the efficacy of the measures. The assessments of adaptation costs were similarly influenced by experience and peer discussions, yet they were principally related to the individual farm management strategies and the availability of economic capital, labour and time. The following quote exemplifies a strict cost-benefit strategy: 'If the subsidy would be cut one bit, the buffer zones would be taken back to cultivation immediately' (Farmer 4:25).

The discussions on efficacy and costs of specific adaptation measures, such as decreased tillage or winter crops, were contested. A common practice of direct sowing, for example, was on one hand perceived as an ideal way to respond to erosion risk, and on the other, as a practice that requires investment in new machinery and results in increased pesticide use. Breeding climate resilient crop varieties and subsoil drainage renewal were less contested measures and acknowledged as efficient adaptation with acceptable costs. Cultivation of permanent grass-lands and other soil enhancing fodder crops in crop rotation were generally regarded as part of good farming practices and as efficient adaptation. However, their economic viability is hindered by the increased distortion of animal and crop husbandry-oriented farms in Uusimaa, and the unwillingness to cultivate crops that have no end user. Social norms were sometimes also 
perceived to prevent the deployment of measures that deviate from the traditional. This is exemplified in a quotation from a farmer who owns and rents fields:

Of course, those rented fields should also be put in fallow or nature management fields, but then the landlord thinks that I am not cultivating them but instead just using them for subsidy money of which I then give him a share. Of course, they need to be cultivated then. (Farmer 6:16). Alternative livelihood strategies, that is, giving up farming altogether or shifting to parttime farming to reduce economic vulnerability, were assessed efficient and realistic, yet extreme and unwanted. These types of transformative measures were related to the increased unexpectedness of climatic conditions and associated with social and political insecurities.

The non-climatic stressors for adaptation were perceived to affect decisionmaking, especially in terms of the continuously low grain market prices and unexpected changes in agricultural and environmental policies that are steered by the EU, and implemented nationally as subsidies and restrictions. However, perceptions of their effects were not unanimous. Environmental subsidies for water management, for example, were considered as incentives when the preference of profit-orientation or environmental values were emphasised. Alternatively, they were seen as limitations, when farming was discussed in terms of good soil quality maintenance and food production, issues associated with social responsibility, pride and preference. Knowledge and access to it were perceived as limiting factors regarding new measures and policies. More precise productivity calculations, timely information on the spreading of plant diseases and accurate allocation of subsoil drainage reparations based on field specific analyses on soil permeability, were discussed as potential novel adaptation measures. However, these are dependent on private service providers and not equally available to all practitioners. The accessibility issue is influenced by the economic situation of individual farms, and also by other less obvious factors, such as lack of craftsmanship or 
contractors. The following quotation from a farmer from the Northern part of the region exemplifies this: 'Draining would be good. But draining is at minimum. In this region, even the draining contractors are old' (Farmer 6:17). In addition, the European Common Agriculture Policy (CAP) was perceived as a restrictive factor to good farming practices that support adaptation.

Non-climatic factors that accentuate vulnerability to climatic challenges through evoking general insecurity, mainly market and policy fluctuations, can also cause less investment in farming in the long-term. In Uusimaa, this is shown, for example, in the rising share of rented fields that receive less attention and care. Water management and soil maintenance measures, such as liming and drainage, are typically not implemented on rented fields on short contracts. The proximity of non-farm related employment and education opportunities in the capital region decrease the incentive for farm work, leading to non-optimal implementation of cultivation practices, renting out of fields, and giving up on animal husbandry. The decreasing animal husbandry in the region was generally perceived problematic for the long-term adaptation in terms of the degree of selfsufficiency of biogenic fertilizers (manure) and the usability of perennial crops (pastures). Furthermore, the participants discussed how the market driven state of current agricultural development could benefit the region in terms of new market opportunities through new production orientation and products, such as organic and local production. However, the lack of long-term vision in the farm scale management and in the agricultural politics generally was raised as a concern.

\section{Adaptation Intention}

In the PMT framework the adaptation assessment is considered to either evoke protection motivation and intention to adapt or no intention to adapt. This section presents 
discussions on adaptation measures that reflect different levels of intention to take adaptation action as well as perceptions of drivers/barriers for intention/action.

The adaptation intentions were discussed at different levels as for what should, could, is and will be done in the region to enable farming within the context of perceived changes in weather and climatic conditions as well as the related risks. Measures discussed at a conditional level (should, could), such as digging up a river bed to prevent flooding of the fields, were situated temporally further in the future, and were related to spatial scales outside of the farm or organisational levels, such as regional planning. More importantly, the participants described measures and strategies that were implemented or planned in a defined time-scale, ranging from a growing season to next generations. They were aimed at reducing the risks or at increasing the coping capacity, the adaptive capacity or the benefits ${ }^{5}$. Emphasis was put on long-term adaptive capacity building, i.e. measures for improving the soil quality, and on capturing the benefits, i.e. capitalizing on climate change. The intended or already implemented measures were targeted to changing to other crops (e.g. cumin), cultivation measures (e.g. direct sowing), field work practices (e.g. deep ploughing), field improvement (e.g. adjustment of sub soil drainage), production structure (e.g. co-operation) or production orientation (e.g. organic). The measures were firstly aimed at farm-level changes, but impacts on the broader scale to local economies, regional productivity, food-production and environment were recognised.

Reflections on the option of not taking adaptation measures were related to lowered perception of self-efficacy and low expectations of the adaptation measure

\footnotetext{
${ }^{5}$ See the supplemental online material for a comprehensive table of the measures.
} 
efficacy or their unbearable costs. The costs were perceived to build up consequentially to the required systemic or temporal scale:

It is nevertheless such a long process to enhance the soil structure [with deep-rooted plant implementation in the crop circulation] that a busy farmer might not come to think about it in long term perspective. (Officer 5:6).

The discussions on maladaptation focused on changes in measure selection and timing, and did not refer to general opposition to adaptation. However, contradictions in the rationale of adaptation and notions of mixed emotions and perceptions related to it were expressed in these discussions. Adaptation was on one hand seen to depend on favourable economic conditions, and on the other hand as an imperative response to the changing conditions to ensure the continuity of farming and food production more generally.

In the end, norms, values and preferences affected how the adaptation intention was discussed. An extension officer characterises the effect of preferences with two polarities:

Of course, those farmers who want to reduce their work load choose buffer zones and nature management fields --- then those who have that labour available and who have their focus on profiting with the crop yield, they concentrate on oil plants, protein plants and grains. They want to cultivate every inch of their fields. It is the standpoint that counts. (Officer 5:31)Similarly, the decision-making at farm level was discussed in relation to a general approach on change. Discussions reflected a determined approach on farm management, such as in the following quotation: 'I will continue this way until the end. It is difficult to make changes then' (Farmer 4:10), or a distinct decision-making style, exemplified in this quotation: 'I have noticed, that I find it much easier sticking to plan A than changing it to plan B somehow' (Farmer 2:66). The adaptation decisions at farm level are thus affected by general perceptions of change. 


\section{Synthesis of the Results}

The considered adaptation measures at farm scale are highly contextual and dynamic. As an example, it was discussed how every decision at the farm is dependent on the profit expectation, while profit was perceived differently depending on the values, preferences, temporal scale of assessment, and assets, such as soil type or machinery. Explanatory patterns for risk perception driven adaptation can be identified as three dominating types of risk responses, see Table 2. These patterns can occur within different parts of the operational farming system (e.g. field work, farm economy or production) and at different temporal scales (e.g. growing season or next generation) and overlap. They are not definers of personality, nor fixed descriptions of behaviour, although they are influenced by the personal sphere of adaptation (values, preferences, etc.).

First, in the risk aversive pattern, the main driver for adaptation is to avoid different climate related risks rather than actively build long-term adaptive capacity or take advantage of the changing situation. These responses reflect to conservative values and lack of incentives on one hand, and to lowered expectations of the efficacy of the measure or the costs on the other. They also exemplify a careful approach and reluctance to being a pioneer, features described as dominating in the farmer population. This results in incremental or reactive changes that can lead to insufficient adaptation. In the following excerpts, this is demonstrated by an official discussing how new practices are adopted at the farm level:

The practical examples are especially needed. Farmers are, however, fairly conservative and the changes take place gradually. First you must see that the neighbour is doing something differently and if it works, you might try it yourself at some point. (Official 4:22).

And, by a farmer describing how he has made decisions regarding new measures:

It's when someone else --- a neighbour, for example, has done it for a while. It's been based on other farmers' experiences then. I haven't needed any advisors or such, no. (Farmer 
Second, in the opportunity seeking pattern, adaptation is predominantly driven by profit expectation, leading to taking economic risks, as well as to seeking for opportunities related to climatic risks. The related adaptation measures, such as the use of agroenvironmental subsidies, minimising work intensity and speculating with market fluctuations, do not necessarily represent a traditional set of agricultural measures, but rather an entrepreneurial approach. In this pattern, increasing the economic room for manoeuvre works as an adaptation strategy through decreasing vulnerability in case of unexpected losses (e.g. crop losses) and investment needs (e.g. replacement seed corn). The logic is exemplified in the following excerpt:

All decisions that I make are based on aiming for best possible profit. This is a limited company and regardless of me being the owner, the Finnish Companies-Act entails this to produce best possible profit for its owners. --- I don't really think about climate change, to be honest. But as I said, the recent decisions: taking up winter crops and giving up spring rape are consequential also to... or the climate change is causing the economic change that affects that decision. (Farmer 7:26)

In another example representing the opportunity seeking pattern, the farmer explains how he made the decision on changing production orientation to organic:

It was when the EU was established and the grain prices dropped. Intensive farming with those prices seemed irrational then. I calculated that it is not economically viable. And the organic idea was not new to me. (Farmer3:2)

Third, in the experimental pattern, climate related risks are regarded as an external pressure that sets new and unprecedented conditions for the whole industry and livelihood. This notion is driving adaptation that firstly seeks to explore novel ways of crop cultivation, farming and food production. These type of risk responses can build up gradually based on small scale experiments (e.g. on a field plot) and observations. This 
is common in farming, as an advisor remarks in the following quotation: 'Although farmers can be very conservative, they nevertheless pay attention to the nature and observe attentively and learn by doing.' (Officer 2:26). However, as the climatic conditions change more rapidly and to a more extreme extent, the pressure to take more extensive and potentially transformative novel measures increases and the trial and error way of experimentation is not viable anymore. The 'innovation farmers' were referred to as a group of farmers, who are most likely to take adaptation to this extent, as an experienced and soon retiring official discussed:

This way of thinking [in longer term] is spreading and it is very useful and I put all my hope in that the long term thinking will accumulate in the farmer expertise more and more. And there are those innovation farmers who have already contemplated these exceptionally far and are also carrying them out. (Officer 5:33)

[Table 2 near here]

\section{Discussion and Conclusions}

The analysis of the agricultural stakeholders' risk perceptions and adaptation decisionmaking shows that adaptation is rather an emerging than a deliberate process at farm scale, and the guiding adaptation policies in the Nordic agricultural context are yet scarce. Moreover, the results suggest that climate risk driven adaptation emerges as three types of risk responses: risk aversive, opportunity seeking and experimental. In particular, this study highlights the contextual and dynamic nature of these risk responses at the Nordic farms.

The results demonstrate that risk perceptions, as well as the adaptation decisionmaking, relate to the three risk response patterns that differ in how the perceived risks 
drive adaptation and potential maladaptation, which is further explained by differences in the perceptions of uncertainties, and the contextual and socio-cognitive factors. Similarly to a Danish study by Jørgensen and Termansen (2016), this study finds that farmers do not have contextually relevant knowledge of climate risks over different time scales. This could restrain the risk aversive pattern, i.e. 'better safe than sorry' response, from taking adaptation measures at all and further expose Nordic agriculture to climate change risks. The opportunity seeking pattern might not take adaptation measures either because the profit expectation is blurred by uncertainty. However, the opportunity seeking pattern is also characterised by taking risks in situations where uncertainty can be capitalized, which in this study indicates potential maladaptation but also potentially larger scale adaptive measures, a notion which is supported in literature (Howden et al., 2007).

The discussions reflecting the risk aversive pattern concern mainly the livelihood and situations with little economic buffer, implying to structural restrictions (see e.g. Jerneck \& Olsson, 2014) and/or conservative values regarding change, implying 'resistance identity' (Rizzo, 2015). By contrast, the discussions reflecting the opportunity seeking patterns concentrate on valuing profit expectation and situations where the farm economy is relatively stable, resonating with the 'productivist' good farmer identity (Morton, McGuire \& Cast, 2016; Rizzo, 2015; Hyland, Jones, Parkhill, Barnes \& Williams, 2015) and entrepreneurial orientation (Jerneck \& Olsson, 2014). Both these patterns highlight the role of policies and markets, and the economic preconditions and expectations for adaptation, which is in line with other Nordic findings on adaptation perceptions (Asplund, 2016). The discussions reflecting the third, experimental pattern, concentrated on building adaptive capacity instead of going around or benefitting from climate risks. Trust in self-capability, social networks and flexibility for action were discussed as preconditions for this pattern, which supports studies stressing the role of 
community and networks in building the perceived adaptive capacity (Adger, 2003; Adger et al., 2009) and adaptation activity (Larsen et al., 2017). The results of this study also indicate that the characteristics of the experimental risk responses are similar to preconditions defined in literature for transformational adaptation measures (Rickards \& Howden, 2012) and they reflect the 'early adopters' of novel measures (Howden et al., 2007).

The perception studies related to adaptation and climate risks have exemplified and theorised the diversity of factors affecting agricultural adaptation and these were also recognised in the discussions with the farmers. These include the past experiences, awareness of extreme weather events and the negative impacts of climate change, such as crop losses (Menapace, Colson \& Raffaelli, 2015; Li et al., 2017; Wilke \& Morton, 2017; Comoé, Finger \& Barjolle, 2014; Larsen et al., 2016). Similarly to the findings of this study, the significance of contextual nature of risk perception formulation and adaptation decision-making have been emphasised in previous studies (Takahashi, Burnham, Terracina-Hartman, Sopchak \& Selfa, 2016; Singh, Dorward \& Osbahr, 2016; Grothmann \& Patt, 2005). Furthermore, the climate risk perceptions of farmers have been identified as part of different dimensions of life: physical health, income, physical assets, production, social relationships, anxiety about personal loss and happiness (Dang et al., 2014b). In this study, risk perceptions at farm level were identified to consist of experiences, expectations and interpretations of vulnerability and exposure to hazard in different parts of the farming system.

Regardless of the focus of this study being on the farm scale, the findings indicate that the climate adaptation and risk responses in agriculture are related to broader societal context. Similarly to others (Abid, Schilling, Scheffran \& Zulfiqar, 2016; Tucker, Eakin \& Castellanos, 2010), this study proposes a focus on the regional factors to address the 
manageability of adaptation in agriculture. The contradictions in the aims of and capabilities for adaptation could be addressed with regional adaptation policies and targeted communication, as Niles, Lubell and Brown (2014) suggest, which nevertheless calls for detailed national adaptation targets to avoid maladaptation that would harm other sectors and sustainable development (Papadimitriou, Holman, Dunford \& Harrison, 2019). Participatory policy planning with multiple stakeholders (see e.g. Ross et al, 2015) could address the potential challenges related to finding socially acceptable transformative adaptation measures as a response to the more pressing needs for transformative changes when the effects of climate change increase (see e.g. Harjanne et al., 2016).

As demonstrated in this study, the adaptation intentions of the Nordic farmers mirror their climate risk perceptions, as well as their farm level risk management practices. The study indicates that the broader functions and standards of the agri-food systems, such as food production and sustainability, are acknowledged but often not considered in farm-scale adaptation decision-making. The participants discussed that adaptation, among other practices on the farm, is challenged by lack of resources for optimised decision-making that would enhance synergies between multiple aims, similar to 'no regret' measures (see e.g. George et al., 2018), climate smart agriculture (CSA) and sustainable intensification (SI) (see e.g. Campbell, Thornton, Zougmoré, Van Asten, and Lipper, 2014). SI and CSA, for example, are studied in the Nordic context with promising results on some aspects, such as improved nutrient recycling, crop productivity and energy self-sufficiency, yet, research gap on trade-offs related to increased use of inputs, food production and greenhouse gas emissions (Koppelmäki et al. 2019; Purola, Lehtonen, Liu, Tao, and Palosuo, 2018) undermines their applicability in adaptation. 
This study indicates that the presented risk response patterns that consider adaptation assessment are applied when no policy guidance or support is provided, and that they do not represent such rational decision-making models that are often used in describing and assessing climate change adaptation (Biesbroek et al., 2015; Holman, Brown, Carter, Harrison, and Rounsevell, 2019). This research thus suggests a focus on the non-climatic stressors that are involved in the emergence/development of the presented risk responses as well as on the potential outcomes of the responses to better understand and assess their effect on the future of the Nordic agri-food systems. The findings of this study particularly point towards a gap in knowledge and action of consistent proactive long-term adaptation in Nordic agri-food systems which the study recommends to approach with participatory science-policy-practice co-production/development, supported by previous calls. Localized communication and adaptation strategies are recommended to build on farmers' perceptions of weather variability and the related coping capability, and expert knowledge on long-term and high-end climate scenarios (Buelow and Cradock-Henry, 2018; Findlater, Donner, Satterfield, and Kandlikar, 2018) and proceed to multi-stakeholder action planning and levelling-up from local to regional scale (Ross et al, 2015).

This study has provided insights to adaptation in a significant Nordic agricultural region. Regardless of the small sample size, the study provides input to the current discussion on adaptation at the practical level and raises some important topics for future studies and policy development considerations. Further and larger sample studies on climate risk responses that would also address the risk of maladaptation in the Nordic agricultural context, are suggested to build understanding on how to support sustainable agricultural adaptation and manage climate risks in participation with stakeholders. This study introduced farmers as the key stakeholders in agricultural climate risk management 
and adaptation, and the agricultural advisors as important stakeholders between the practical and the policy level. Future adaptation research and policy development is suggested to include a broader spectrum of the agri-food system stakeholders, to better understand the multiple perspectives and uncertainties related to preconditions for taking climate adaptation measures that support agricultural sustainability.

\section{References}

Abid, M., Schilling, J., Scheffran, J. \& Zulfiqar, F. (2016). Climate change vulnerability, adaptation and risk perceptions at farm level in Punjab, Pakistan. Science of the Total Environment, 547, 447-460.

Adger, W.N. (2003). Social capital, collective action, and adaptation to climate change. Economic geography, 79(4), 387-404.

Adger, W.N., Dessai, S., Goulden, M., Hulme, M., Lorenzoni, I., Nelson, D.R., Naess, L.O., Wolf, J. \& Wreford, A. (2009). Are there social limits to adaptation to climate change? Climatic change, 93(3), 335-354.

Asplund, T. (2016). Natural versus anthropogenic climate change: Swedish farmers' joint construction of climate perceptions. Public Understanding of Science, 25(5), 560-575.

Atkinson, R. \& Flint, J. (2001). Accessing hidden and hard-to-reach populations: Snowball research strategies. Social research update, 33(1), 1-4.

Aven, T., \& Renn, O. (2009). On risk defined as an event where the outcome is uncertain. Journal of risk research, 12(1), 1-11.

Biesbroek, R., Dupuis, J., Jordan, A., Wellstead, A., Howlett, M., Cairney, P., Rayner, J., Davidson, D., 2015. Opening up the black box of adaptation decisionmaking. Nature Climate Change, 5, 493-494. 
Buelow, F. and Cradock-Henry, N. (2018). What You Sow Is What You Reap? (Dis-) Incentives for Adaptation Intentions in Farming. Sustainability, 10(4),1133.

Campbell, B.M., Thornton, P., Zougmoré, R., Van Asten, P. and Lipper, L. (2014). Sustainable intensification: What is its role in climate smart agriculture? Current Opinion in Environmental Sustainability, 8, 39-43.

Comoé, H., Finger, R. \& Barjolle, D. (2014). Farm management decision and response to climate variability and change in Côte d'Ivoire. Mitigation and adaptation strategies for global change, 19(2), 123-142.

Dang, H., Li, E., Nuberg, I. \& Bruwer, J. (2014a). Understanding farmers' adaptation intention to climate change: a structural equation modelling study in the Mekong Delta, Vietnam. Environmental Science \& Policy, 41, 11-22.

Dang, H., Li, E., Nuberg, I. \& Bruwer, J. (2014b). Farmers' perceived risks of climate change and influencing factors: a study in the Mekong Delta, Vietnam. Environmental management, 54(2), 331-345.

Dang, H., Li, E., Nuberg, I. \& Bruwer, J. (2014c). Farmers' assessments of private adaptive measures to climate change and influential factors: a study in the Mekong Delta, Vietnam. Natural hazards, 71(1), 385-401.

Dessai, S., Adger, W.N., Hulme, M., Turnpenny, J., Köhler, J. \& Warren, R. (2004). Defining and experiencing dangerous climate change. Climatic Change, 64(1), $11-25$.

ELY: Uudenmaan elinkeino- liikenne ja ympäristökeskus (2012). Uudenmaan maaseudun kehittämisstrategia 2020 [Development strategy for the rural Uusimaa 2020], Retrieved from https://www.ely-keskus.fi/documents/10191/58584/Uudenmaan+maaseudun+ke hitt\%C3\%A4misstrategia/81ecf00a-fa85-4e9a-a978-9799cf91645b 
Eriksson, L. (2014). Risk perception and responses among private forest owners in Sweden. Small-scale forestry, 13(4), 483-500.

Findlater, K.M., Donner, S.D., Satterfield, T. and Kandlikar, M. (2018). Integration anxiety: The cognitive isolation of climate change. Global Environmental Change, 50, 178-189.

Gardezi, M., \& Arbuckle Jr, J. G. (2017). Spatially Representing Vulnerability to Extreme Rain Events Using Midwestern Farmers' Objective and Perceived Attributes of Adaptive Capacity. Risk Analysis, 39(1), 17-34.

George, D.A., Clewett, J.F., Lloyd, D., McKellar, R., Tan, P.L., Howden, ... Barlow, S. (2018). Research priorities and best practices for managing climate risk and climate change adaptation in Australian agriculture. Australasian Journal of Environmental Management: 1-19.

Grothmann, T. \& Patt, A. (2005). Adaptive capacity and human cognition: the process of individual adaptation to climate change. Global Environmental Change, 15(3), 199-213.

Halperin, S. \& Heath, O. (2012). Political Research: Methods and Practical Skills. Oxford, UK: Oxford University Press.

Harjanne, A., Haavisto, R., Tuomenvirta, H., Luhtala, S., Mäkelä, A., Gregow. H., ... Kollanus, V. (2016). Sää- ja ilmastoriskien hallinta ja tietolähteet Suomessa [Management of weather and climate risks and the use of related information sources in Finland]. Helsinki, Finland: Finnish Meteorological Institute, Reports 2016:6.

Hirsjärvi, S. \& Hurme, H. (2015). Tutkimushaastattelu: Teemahaastattelun Teoria Ja Käytäntö. [Research interview: The Theory and Practice of Thematic interview]. Helsinki: Gaudeamus. 
Holman, I.P., Brown, C., Carter, T.R., Harrison, P.A., Rounsevell, M. (2019).

Improving the representation of adaptation in climate change impact models. Regional Environmental Change, 19, 711-721.

Howden, S.M., Soussana, J.F., Tubiello, F.N., Chhetri, N., Dunlop, M. \& Meinke, H. (2007). Adapting agriculture to climate change. Proceedings of the national academy of sciences, 104(50), 19691-19696.

Hyland, J.J., Jones, D.L., Parkhill, K.A., Barnes, A.P. \& Williams, A.P (2016). Farmers' perceptions of climate change: identifying types. Agriculture and human values, 33(2), 323-339.

Jerneck, A., \& Olsson, L. (2014). Food first! Theorising assets and actors in agroforestry: risk evaders, opportunity seekers and 'the food imperative' in subSaharan Africa. International journal of agricultural sustainability, 12(1), 1-22.

Juhola, S., Klein, N., Käyhkö, J. \& Neset, T.S.S. (2017). Climate change transformations in Nordic agriculture? Journal of Rural Studies, 51, 28-36.

Juhola, S., Glaas, E., Linnér, B.O. \& Neset, T.S. (2016a). Redefining maladaptation. Environmental Science \& Policy, 55, 135-140.

Juhola, S., Kokko, K., Ollikainen, M., Peltonen-Sainio, P., Haanpää, S., Seppälä, J., .. Airaksinen, M. (2016b). Ilmastonmuutoksen riskit, kustannukset ja vastuut: tapaustarkastelussa sato- ja tulvavahingot [Risks, costs and responsibilities of climate change: a case study of flood and crop insurances]. Helsinki, Finland: The Finnish Climate Change Panel, Report 2016:2, Retrieved from http://www.ilmastopaneeli.fi/uploads/selvitykset_lausunnot/ilmastopaneeli_ilma stomuutoksen\%20riskit\%202016.pdf

Jørgensen, S.L. \& Termansen, M. (2016). Linking climate change perceptions to adaptation and mitigation action. Climatic Change, 138(1-2), 283-296. 
Keshavarz, M. \& Karami, E. (2014). Farmers' decision-making process under drought. Journal of Arid Environments, 108, 43-56.

Keskitalo, E.C.H. (ed.) (2010). Developing Adaptation Policy and Practice In Europe: Multi-Level Governance of Climate Change. Dordrecht: Springer.

Klein, R.J. \& Juhola, S. (2014). A framework for Nordic actor-oriented climate adaptation research. Environmental Science \& Policy, 40, 101-115.

Keski-Uudenmaan Ympäristökeskus (2013). KUUMA -kunnat, ilmastonmuutokseen sopeutumisohje [KUUMA municipalities, instructions for climate change adaptation]. Tuusula, Finland: Keski-Uudenmaan Ympäristökeskus, Retrieved from http://www.kuumailmasto.fi/kuumailmasto/attachments/text_editor/26877.pdf?c hecksum =b413ba475b3f45e2359cff4ee3dcfd27\&name=Sopeutumisohje

Koppelmäki, K., Parviainen, T., Virkkunen, E., Winquist, E., Schulte, R.P. and Helenius, J. (2019). Ecological intensification by integrating biogas production into nutrient cycling: Modeling the case of Agroecological Symbiosis. Agricultural systems, 170, 39-48.

Larsen, R.K., Swartling, Å.G., Powell, N., May, B., Plummer, R., Simonsson, L. \& Osbeck, M. (2012). A framework for facilitating dialogue between policy planners and local climate change adaptation professionals: Cases from Sweden, Canada and Indonesia. Environmental science \& policy, 23, 12-23.

Li, S., Juhász-Horváth, L., Harrison, P.A., Pintér, L. \& Rounsevell, M.D. (2017). Relating farmer's perceptions of climate change risk to adaptation behaviour in Hungary. Journal of environmental management, 185, 21-30.

Lebel, P., Whangchai, N., Chitmanat, C., Promya, J. \& Lebel, L. (2015). Perceptions of climate-related risks and awareness of climate change of fish cage farmers in northern Thailand. Risk Management, 17(1), 1-22. 
van der Linden, S. (2014). On the relationship between personal experience, affect and risk perception: The case of climate change. European journal of social psychology, 44(5), 430-440.

Lipper, L., Thornton, P., Campbell, B.M., Baedeker, T., Braimoh, A., Bwalya, M., ... Hottle, R. (2014). Climate-smart agriculture for food security. Nature climate change, 4(12), 1068- 1072.

Malterud, K., Siersma, V.D. \& Guassora, A.D. (2016). Sample size in qualitative interview studies: guided by information power. Qualitative health research, 26(13), 1753-1760.

Maracchi, G., Sirotenko, O. \& Bindi, M. (2005). Impacts of present and future climate variability on agriculture and forestry in the temperate regions: Europe. Climatic Change, 70(1-2), 117-135.

Menapace, L., Colson, G. \& Raffaelli, R. (2015). Climate change beliefs and perceptions of agricultural risks: An application of the exchangeability method. Global Environmental Change, 35, 70-81.

Morton, L.W., McGuire, J.M. \& Cast, A.D. (2017). A good farmer pays attention to the weather. Climate Risk Management, 15, 18-31.

Neset, T-S., Wiréhn. L., Klein, N., Käyhkö, J. \& Juhola, S. (2018). Maladaptation in Nordic Agriculture. Climate Risk Management, In press, 10.1016/j.crm.2018.12.003

Niles, M.T., Lubell, M. \& Brown, M. (2015). How limiting factors drive agricultural adaptation to climate change. Agriculture, Ecosystems \& Environment, 200, $178-185$

Noble, I.R., Huq, S. Anokhin, Y.A., Carmin, J., Goudou, D., Lansigan, F.P., ... Villamizar, A. (2014). Adaptation needs and options. In: Field, C.B., Barros, V.R., Dokken, D.J., Mach, K.J., Mastrandrea, M.D., Bilir, T.E., ... White, L.L. 
(eds.) Climate Change 2014: Impacts, Adaptation, and Vulnerability. Part A: Global and Sectoral Aspects. Contribution of Working Group II to the Fifth Assessment Report of the Intergovernmental Panel on Climate Change. Cambridge University Press, Cambridge, United Kingdom and New York, NY, USA, pp. 1039-1099.

Norman, P., Boer, H. \& Seydel, E. R. (2005). Protection motivation theory. In: Conner, M. \& Norman, P. (eds.) Predicting Health Behaviour: Research and Practice with Social Cognition Models. Maidenhead: Open University Press, pp. 81-126.

Olesen, J.E. \& Bindi, M. (2002). Consequences of climate change for European agricultural productivity, land use and policy. European journal of agronomy, 16(4), 239-262.

Oppenheimer, M., Campos, M., Warren, R., Birkmann, J., Luber, G., O’Neill, B. \& Takahashi, K. (2014) Emergent risks and key vulnerabilities. In: Field, C.B., Barros, V.R., Dokken, D.J., Mach, K.J., Mastrandrea, M.D., Bilir, T.E., ... White, L.L. (eds.) Climate Change 2014: Impacts, Adaptation, and Vulnerability. Part A: Global and Sectoral Aspects. Contribution of Working Group II to the Fifth Assessment Report of the Intergovernmental Panel on Climate Change. Cambridge University Press, Cambridge, United Kingdom and New York, NY, USA, pp. 1039-1099.

Papadimitriou, L., Holman, I.P., Dunford, R. and Harrison, P.A. (2019). Trade-offs are unavoidable in multi-objective adaptation even in a post-Paris Agreement world. Science of the Total Environment, 696,134027.

Peltonen-Sainio, P., Sorvali, J., Müller, M., Huitu, O., Neuvonen, S., Nummelin, T. ... Kumpula, J. (2017). Sopeutumisen tila 2017: Ilmastokestävyyden tarkastelut maa- ja metsätalousministeriön hallinnonalalla [State of adaptation 2017: Assessment of climate sustainability in the administrative sector of the Ministry of agriculture and forestry]. Helsinki: Luonnonvarakeskus, Luonnonvara- ja biotalouden tutkimus 2017:18. 
Peltonen-Sainio, P. \& Jauhiainen, L. (2014). Lessons from the past in weather variability: sowing to ripening dynamics and yield penalties for northern agriculture from 1970 to 2012. Regional environmental change, 14(4), 15051516.

Purola, T., Lehtonen, H., Liu, X., Tao, F. and Palosuo, T. (2018). Production of cereals in northern marginal areas: An integrated assessment of climate change impacts at the farm level. Agricultural systems, 162,191-204.

Rickards, L., Ison, R., Fünfgeld, H. \& Wiseman, J. (2014). Opening and closing the future: climate change, adaptation, and scenario planning. Environment and Planning C: Government and Policy, 32(4), 587-602.

Rizzo, F. (2016) Approaching Multifunctionality by a 'Normative View': Finnish Farmers' Visions on Contemporary Agriculture. European Countryside, 8(1), $16-32$.

Rogers, R.W. (1975) A protection motivation theory of fear appeals and attitude change. The journal of psychology, 91(1), 93-114.

Rogers, R.W. (1983) Cognitive and psychological processes in fear appeals and attitude change: A revised theory of protection motivation. In: Cacioppo, J. T. \& Petty, R. (eds.) Social psychophysiology: A sourcebook. Guilford Press, New York, pp. 153-176.

Ross, H., Shaw, S., Rissik, D., Cliffe, N., Chapman, S., Hounsell, V., ... Schoeman, J. (2015). A participatory systems approach to understanding climate adaptation needs. Climatic Change, 129(1-2), 27-42.

Räsänen, A., Juhola, S., Nygren, A., Käkönen, M., Kallio, M., Monge, A. M., \& Kanninen, M. (2016). Climate change, multiple stressors and human vulnerability: a systematic review. Regional Environmental change, 16(8), 2291-2302. 
Singh, C., Dorward, P. \& Osbahr, H. (2016). Developing a holistic approach to the analysis of farmer decision-making: Implications for adaptation policy and practice in developing countries. Land Use Policy, 59, 329-343.

Slovic, P. (2000). The Perception of Risk. London: Earthscan Publications.

Smit, B. \& Skinner, M.W. (2002). Adaptation options in agriculture to climate change: a typology. Mitigation and adaptation strategies for global change, 7(1), 85114.

Stirling, A. (2007). Risk, precaution and science: towards a more constructive policy debate: Talking point on the precautionary principle. EMBO reports, 8(4), 309315.

Takahashi, B., Burnham, M., Terracina-Hartman, C., Sopchak, A.R. \& Selfa, T. (2016). Climate Change Perceptions of NY State Farmers: The Role of Risk Perceptions and Adaptive Capacity. Environmental management, 58(6), 946-957.

Thomalla, F., Downing, T., Spanger-Siegfried, E., Han, G. \& Rockström, J. (2006). Reducing hazard vulnerability: towards a common approach between disaster risk reduction and climate adaptation. Disasters, 30(1), 39-48.

Treby, E., Clark, M., \& Priest, S. (2006). Confronting flood risk: Implications for insurance and risk transfer. Journal of environmental management, 81, 351-359.

Tucker, C.M., Eakin, H. \& Castellanos, E.J. (2010). Perceptions of risk and adaptation: Coffee producers, market shocks, and extreme weather in Central America and Mexico. Global Environmental Change, 20(1), 23-32.

Welp, M., de la Vega-Leinert, A., Stoll-Kleemann, S. \& Jaeger, C.C. (2006). Sciencebased stakeholder dialogues: Theories and tools. Global Environmental Change, 16(2), 170-181. 
Wilke, A.K. \& Morton, L.W. (2017). Analog years: Connecting climate science and agricultural tradition to better manage landscapes of the future. Climate Risk Management, 15, 32-44.

Wiréhn, L. (2018). Nordic agriculture under climate change: A systematic review of challenges, opportunities and adaptation strategies for crop production. Land Use Policy, 77, 63-74.

Woods, B.A., Nielsen, H.Ø., Pedersen, A.B. \& Kristofersson, D. (2017). Farmers' perceptions of climate change and their likely responses in Danish agriculture. Land Use Policy, 65, 109-120.

Vulturius, G., André, K., Swartling, Å. G., Brown, C., Rounsevell, M. D., \& Blanco, V. (2018). The relative importance of subjective and structural factors for individual adaptation to climate change by forest owners in Sweden. Regional Environmental Change, 18(2), 511-520.

Yin, R.K. (2014). Case Study Research: Design and Methods. Fifth edition. Thousand Oaks, California, US: SAGE publications.

Table 1. List of participants and interview details.

\begin{tabular}{c|l|l} 
& Participants & Interview \\
\hline Extension & County Officials (n=2; male) & 60 min., in Finnish, at participant's work \\
Officers & places
\end{tabular}




\begin{tabular}{|c|c|c|}
\hline & Agricultural Advisors ( $\mathrm{n}=2$; male) & $\begin{array}{l}\text { 75-100 min., in Finnish, at participant's } \\
\text { work places }\end{array}$ \\
\hline & $\begin{array}{l}\text { Representatives of Farmers Union }(n=2 ; \\
1 \text { male, } 1 \text { female })\end{array}$ & $\begin{array}{l}60 \text { min., in Finnish, at participant's work } \\
\text { places }\end{array}$ \\
\hline \multirow[t]{3}{*}{ Farmers } & $\begin{array}{l}\text { Organic Farmer, mainly rye and wheat } \\
(\mathrm{n}=1 ; \text { male })\end{array}$ & 60 min., in Finnish, at the farm \\
\hline & $\begin{array}{l}\text { Conventional Farmers, mainly oat, } \\
\text { wheat, rye and barley ( } \mathrm{n}=5 ; 4 \text { male, } 1 \\
\text { female) }\end{array}$ & 60-80 min., in Finnish, at the farms \\
\hline & $\begin{array}{l}\text { Conventional Farmer, mainly } \\
\text { strawberries and varying grains ( } \mathrm{n}=1 \text {; } \\
\text { male) }\end{array}$ & 60 min., in Finnish, at the farm \\
\hline
\end{tabular}

Table 2. Typology of the risk response types in adaptation decision-making process (according to the PMT framework): characterising factors and examples from the interviews. 


\begin{tabular}{|c|c|c|c|}
\hline & Risk aversive & $\begin{array}{l}\text { Opportunity - } \\
\text { seeking }\end{array}$ & Experimental \\
\hline $\begin{array}{l}\text { Climate risks } \\
\text { regarded as: }\end{array}$ & $\begin{array}{l}\text { limiting factors for } \\
\text { conservative or } \\
\text { careful behaviour }\end{array}$ & $\begin{array}{l}\text { opportunities or } \\
\text { limiting factors for } \\
\text { profit seeking }\end{array}$ & $\begin{array}{l}\text { imperatives for } \\
\text { change }\end{array}$ \\
\hline $\begin{array}{l}\text { Adaptation } \\
\text { intention }\end{array}$ & $\begin{array}{l}\text { When necessary; } \\
\text { rather see what } \\
\text { neighbours do } \\
\text { first; the minimum } \\
\text { cost principle }\end{array}$ & $\begin{array}{l}\text { When } \\
\text { economically } \\
\text { optimal; success of } \\
\text { others observed }\end{array}$ & $\begin{array}{l}\text { Proactive; } \\
\text { preparatory small- } \\
\text { scale experiments; } \\
\text { learning by doing \& } \\
\text { sharing }\end{array}$ \\
\hline $\begin{array}{l}\text { Adaptation } \\
\text { measures } \\
\text { (the predominant } \\
\text { intention) }\end{array}$ & $\begin{array}{l}\text { Incremental, risk } \\
\text { reductive, and/or } \\
\text { coping capacity } \\
\text { building measures }\end{array}$ & $\begin{array}{l}\text { Capitalizing } \\
\text { measures or not } \\
\text { taking measures at } \\
\text { all }\end{array}$ & $\begin{array}{l}\text { Adaptive capacity } \\
\text { building measures }\end{array}$ \\
\hline $\begin{array}{l}\text { Maladaptation } \\
\text { potentially } \\
\text { resulting from: }\end{array}$ & $\begin{array}{l}\text { small scale or } \\
\text { personal sphere } \\
\text { focus of action }\end{array}$ & economic losses & $\begin{array}{l}\text { on-going } \\
\text { experimentations } \\
\text { without observable } \\
\text { results }\end{array}$ \\
\hline Examples & $\begin{array}{l}\text { Careful approach: } \\
\text { 'not putting all } \\
\text { eggs in the same } \\
\text { basket'; } \\
\text { conservative } \\
\text { values }\end{array}$ & $\begin{array}{l}\text { Priority on the } \\
\text { economic benefit: } \\
\text { 'everything is done } \\
\text { with profit firstly } \\
\text { in mind' }\end{array}$ & $\begin{array}{l}\text { Visionary mentality; } \\
\text { 'passion for } \\
\text { farming'; } \\
\text { 'innovation farmers' }\end{array}$ \\
\hline
\end{tabular}

Figure 1. Risk perception driven adaptation decision-making model based on protection motivation theory (PMT) (applied from Norman et al., 2005; Grottham \& Patt, 2005;

Smitt \& Skinner, 2002). 